\title{
Drying characteristics and prediction of best fitted drying model for coriander leaves
}

Sanjay Kumar Singh $ه$

Farm Machinery and Post-Harvest Technology Division, ICAR- Indian Grassland and Fodder Research Institute, Jhansi, India

Samsher

S.V.P. University of Agric. \& Tech., Meerut, U. P., India

B R Singh

S.V.P. University of Agric. \& Tech., Meerut, U. P., India

R S Sengar

S.V.P. University of Agric. \& Tech., Meerut, U. P., India

Pankaj Kumar

S.V.P. University of Agric. \& Tech., Meerut, U. P., India

Amit Kumar Patil

Farm Machinery and Post-Harvest Technology Division, ICAR- Indian Grassland and Fodder Research Institute, Jhansi, India

\begin{tabular}{|c|c|}
\hline ARTICLE INFO & ABSTRACT \\
\hline $\begin{array}{l}\text { Received : } 30 \text { June } 2021 \\
\text { Revised : } 20 \text { August } 2021 \\
\text { Accepted : } 30 \text { August } 2021 \\
\text { Available online: } 9 \text { December } 2021 \\
\text { Key Words: } \\
\text { Coriander } \\
\text { Solar greenhouse dryer } \\
\text { Drying rate } \\
\text { Moisture } \\
\text { Drying model }\end{array}$ & $\begin{array}{l}\text { Drying experiments were conducted on coriander leaves as affected by drying } \\
\text { methods (solar greenhouse drying and open sun drying), pretreatments (dipping in } \\
\text { a solution of magnesium chloride }+ \text { sodium bicarbonate }+ \text { potassium } \\
\text { metabisulphite, boiled water blanching containing sodium metabisulphite, and } \\
\text { untreated), and loading densities }\left(2.0,2.5 \text { and } 3.0 \mathrm{~kg} / \mathrm{m}^{2}\right) \text {. Validity of three } \\
\text { commonly used drying models were examined to predict the most suitable drying } \\
\text { model for coriander leaves. The increased drying temperature under solar } \\
\text { greenhouse dryer }\left(42^{\circ} \mathrm{C}\right) \text { increases the amount of moisture removal by } 99.3 \% \\
\text { from the coriander leaves and reduces the drying time by increasing the drying } \\
\text { rate }\left(1.44 \% \text { db/min) as compared to open sun drying }\left(29^{\circ} \mathrm{C}\right) \text {, at all the selected }\right. \\
\text { levels of pretreatments and loading densities. Chemically treated coriander leaves } \\
\text { dehydrated under a solar greenhouse dryer required } 28.6 \% \text { less drying time than } \\
\text { other treated and dried leaves. Nevertheless, drying methods and loading densities } \\
\text { had significant effects, while treatment effects were marginal. It was found that } \\
\text { reduction of moisture (due to migration of moisture from inner core to the outer } \\
\text { surface followed by evaporation of moisture from the outer surface) and moisture } \\
\text { removal rate per unit time occurred mostly in the falling rate period except some } \\
\text { accelerated removal of moisture (present in the outer surface) at the beginning up } \\
\text { to } 150 \text { minutes. Page's model was found most appropriate for drying coriander } \\
\text { leaves followed by Generalized exponential model and Lewis model. }\end{array}$ \\
\hline
\end{tabular}

\section{Introduction}

The coriander (Coriandrum sativum) leaves are rich Sun drying is traditionally an oldest method to in vitamin $\mathrm{A}$ ( $\beta$ - carotene), vitamin $\mathrm{C}$, thiamine, zinc, fibre and low in saturated fat and cholesterol. Fresh coriander leaves consist of $84 \%$ moisture (Bhat et al., 2014). Due to high moisture and improper post-harvest management, the losses in fruits and vegetables were estimated to be $10-40$ \% (Kaya et al., 2007 and El-Sebaii et al., 2012). preserve cereals, pulses, fruits, and vegetables, but this method involves quantitative and qualitative losses because of direct exposure to the sun, dirt, soil, insects, microbes, and other biotic factors. Therefore, solar greenhouse drying can be used as an alternative advanced technique to reduce post harvest losses, maintaining the final qualitative

Corresponding author E-mail: sksingh7770@yahoo.com

Doi: https://doi.org/10.36953/ECJ.2021.22329

This work is licensed under Attribution-Non Commercial 4.0 International (CC BY-NC 4.0)

(C) ASEA 
characteristics of dehydrated goods compared to fresh produce.

Passive solar greenhouse dryer is a covered structure with recommended glazing materials, inside which the crop could be dried due to greenhouse effect. Due to faster removal of moisture under the dryer, drying time is reduced, and better dehydrated product is obtained (Singh et al., 2020a and Singh et al., 2020b). Blanching of vegetables is commonly done to retain the color and texture and inactivation of enzymes such as peroxidase (Oliveira et al., 2016). Kaur et al. (2006) also investigated the qualitative parameters of processed vegetables with respect to pretreatments and air temperatures. Loading density (weight of fresh coriander leaves per unit area kept on drying tray) also play an important role in drying of leafy vegetables. Singh et al. (2020c) studied the economic viability of solar dryer and found it technically and economically suitable for drying and dehydration of coriander. Jain et al. (2000) reported dehydration characteristics of spinach at uniform loading rate of $2 \mathrm{~kg} / \mathrm{m}^{2}$. Drying characteristics of vegetables and fruits have been reported by several researchers, some of which includes on okra slices (Wankhade et al., 2013), moringa leaves (Ali et al., 2014) and leafy vegetables (Pati et al., 2015). However, thorough investigation of drying properties of coriander leaves using solar greenhouse dryers at different levels of pretreatment and loading densities is not reported so far. Therefore, the present study was focused on the change of moisture content, drying rate, and moisture ratio of coriander leaves inside and outside passive solar greenhouse dryer at different levels of pretreatments and loading densities.

\section{Material and Methods \\ Materials}

Sample: Coriander (cv. Pant Haritma) was arranged from Horticultural Research Centre of Sardar Vallabhbhai Patel University of Agriculture \& Technology, Meerut, India, and washed thoroughly in fresh water so as to remove roots and other unwanted materials.

Experimental set-up: A solar greenhouse dryer $(5 \mathrm{~m} \times 3 \mathrm{~m} \times 2.3 \mathrm{~m})$ consisted of drying chamber oriented towards east-west direction and covered with 200 micron UV stabilized polyethylene sheet developed at Horticultural Research Centre of SVP University of Agri. \& Tech., Meerut, India was used for present investigation. Other components of solar greenhouse dryer were (i) insulated and black painted floor (ii) $0.13 \mathrm{~m}$ wide air inlet opening on south wall, and (iii) L shape (1.5 m length) air outlets on the north wall. Temperature and relative humidity were measured using digital $\mathrm{RH} /$ Temperature recorder $\left(0\right.$ to $200{ }^{0} \mathrm{C}$, least count: $0.1^{\circ} \mathrm{C}$ ), and $42{ }^{\circ} \mathrm{C}$ (RH: $33 \%$ ) inside the solar greenhouse dryer and $29{ }^{\circ} \mathrm{C}(\mathrm{RH}: 37 \%)$ at ambient were observed. The air speed inside and outside the dryer was measured by hot wire anemometer (air flow, model TA5), and the weight of coriander leaves during drying with the help of electronic balance (precision: $\pm 0.1 \mathrm{~g}$ ).

\section{Methods}

Experimental procedure: Dehydration study of washed coriander leaves was conducted as shown in Figure 1. Experiments were performed at three drying conditions considering two levels of drying methods (SGD: solar greenhouse drying and OSD: open sun drying), three levels of pretreatments (CT: Chemical treatment $0.1 \%$ magnesium chloride +2 $\%$ potassium metabisulphate $+0.1 \%$ sodium bicarbonate for $15 \mathrm{~min}$, $\mathrm{BW}$ : boiling water treatment of $0.5 \% \mathrm{Na}_{2} \mathrm{~S}_{2} \mathrm{O}_{5}$ for $2 \mathrm{~min}$, and UT: untreated i.e. control), and three levels of loading densities (L1: $2.0 \mathrm{~kg} / \mathrm{m}^{2}, \mathrm{~L} 2: 2.5 \mathrm{~kg} / \mathrm{m}^{2}$, and L3: 3.0 $\mathrm{kg} / \mathrm{m}^{2}$ ). These levels of pretreatments and loading densities were chosen as per previous findings (Kaur et al., 2006; Singh, et al., 2006) with three replications at each levels of drying conditions. Pretreated samples with respective loading densities were spread onto trays in single layer of about 10 $\mathrm{mm}$ thickness inside and outside the solar greenhouse dryer during day time (10 AM to 5 PM). The samples were weighed at the intervals of 30 min. Afterward, the samples were kept in air tight plastics sheet during night and the samples were again dried on the next day till the completion of dehydration of coriander leaves.

Drying analysis: The method recommended by Ranganna (1986) was used to calculate the moisture content $(\mathrm{MC})$ on $\%$ dry basis $(\% \mathrm{db})$ :

$\mathrm{MC}=\left(\mathrm{W}-\mathrm{W}_{\mathrm{d}}\right) \times 100 / \mathrm{W}_{\mathrm{d}}$, where $\mathrm{W}$ is the weight of sample at any time $(\mathrm{g})$, and $\mathrm{W}_{\mathrm{d}}$ the weight of dry material in the sample $(\mathrm{g})$.

The drying rate (DR) was calculated as: 
$\mathrm{DR}=\left(\mathrm{M}_{\mathrm{t}}-\mathrm{M}_{\mathrm{t}+\Delta \mathrm{t}}\right) / \Delta \mathrm{t}$, where $\mathrm{M}_{\mathrm{t}}$ is the moisture content of the product at any time $t(\% \mathrm{db}), \mathrm{M}_{\mathrm{t}+\Delta t}$ the moisture content at time $\mathrm{t}+\Delta \mathrm{t}(\% \mathrm{db})$ and $\mathrm{t}$ the time at any instant ( $\mathrm{min}$ ).

The overall drying rate $(\mathrm{ODR})=\left(\mathrm{M}_{\mathrm{o}}-\mathrm{M}_{\mathrm{F}}\right) / \mathrm{t}_{\mathrm{T}}$, where $\mathrm{M}_{\mathrm{o}}$ and $\mathrm{M}_{\mathrm{F}}$ are initial and final moisture contents $(\% \mathrm{db})$, and $\mathrm{t}_{\mathrm{T}}$ the total drying time $(\mathrm{min})$.

The moisture ratio (MR) is dimensionless and represents the unaccomplished $\mathrm{MC}$ (or moisture):

$\mathrm{MR}=\left(\mathrm{M}_{\mathrm{t}}-\mathrm{M}_{\mathrm{e}}\right) /\left(\mathrm{M}_{\mathrm{o}}-\mathrm{M}_{\mathrm{e}}\right)$, where $\mathrm{M}_{\mathrm{t}}$ is moisture content of the product at any time, and $\mathrm{M}_{\mathrm{e}}$ the equilibrium moisture content. Here $\mathrm{M}_{\mathrm{e}}$ values are very less than the values of $\mathrm{M}_{\mathrm{o}}$ and $\mathrm{M}_{\mathrm{t}}$, therefore,
$\mathrm{M}_{\mathrm{F}}$ was taken in place of $\mathrm{M}_{\mathrm{e}}$. Thus, $\mathrm{MR}$ can be simplified as $\left(\mathrm{M}_{\mathrm{t}}-\mathrm{M}_{\mathrm{f}}\right) /\left(\mathrm{M}_{\mathrm{o}}-\mathrm{M}_{\mathrm{f}}\right)$.

Model fitting of drying data: The values of moisture ratios for the samples of coriander leaves were used for testing the following (Table 1) commonly used models and the best fit model was predicted on the basis of $\mathrm{R}^{2}$ (coefficient of determination) and SEE (standard error of estimation).

Statistical Analysis: The experimental data of dehydrated coriander leaves were analysed graphically using the software viz. EXCEL and MINITAB.

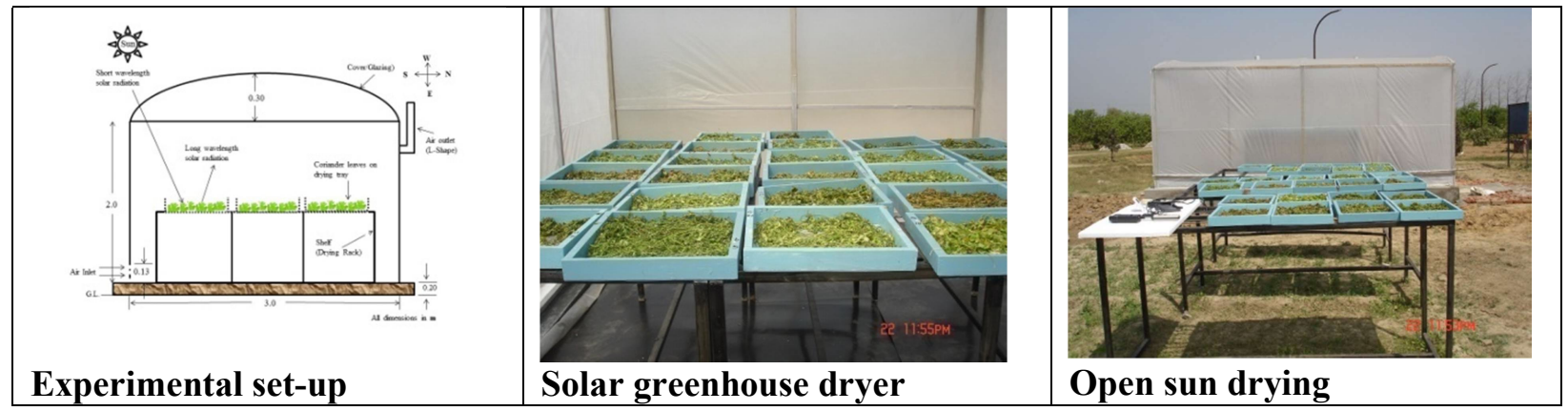

Figure 1: Experimental views of dehydration of coriander leaves.

Table 1: Commonly used mathematical drying models

\begin{tabular}{|l|l|l|}
\hline Model & Name & References \\
\hline $\mathrm{MR}=\mathrm{e}^{-\mathrm{kt}}$ & Lewis model & Bruce, 1985 \\
\hline $\mathrm{MR}=\mathrm{e}^{-\mathrm{kt}^{\mathrm{n}}}$ & Page's model & Sarimeseli, 2011 \\
\hline $\mathrm{MR}=A \mathrm{e}^{-\mathrm{kt}}$ & Generalized exponential model & Pande et al., 2000 \\
\hline
\end{tabular}

$K$ : drying constant, $A, B$ and $t$ : equation constants.

\section{Results and Discussion Moisture Content (MC)}

The values of $\mathrm{M}_{\mathrm{o}}$ were observed in the range of 627.24 to $714.33 \%(\mathrm{db})$. The change in MC with respect to time at different treatments under SGD) and OSD at three levels of loading densities were plotted (Figure 2 to Figure 7). The graphs show non linear relationship between $\mathrm{MC}$ and drying time. Initially, MC decreased slowly during first hour because of low temperature in the morning, and very short constant rate period as also observed by Hallstrom et al. (2006). Akonor et al. (2012) reported longer falling rate period, a phenomenon characteristics of food products. Singh et al., (2017) also observed major part of drying in falling rate period with exception of some initial acceleration period during of berseem under solar dryer. $\mathrm{MC}$ decreased rapidly during the drying period of 60 to 150 min due to warming of inside chamber and absorption of more heat by the product (faster drying) then $\mathrm{MC}$ decreased slowly i.e. falling rate period started after $150 \mathrm{~min}$. Due to diffusion of water from inner surface to outer surface, drying took place. During first $60 \mathrm{~min}$ of drying, decrease in moisture was $41.55 \%$ and in the next $90 \mathrm{~min}$, the decrease was $322.27 \%$. During the last $30 \mathrm{~min}$, the reduction of moisture was only $2.32 \%$. Drying time of $450 \mathrm{~min}$ for CT at 2.0 and $2.5 \mathrm{~kg} / \mathrm{m}^{2}$ inside the SGD, and $720 \mathrm{~min}$ were observed for boiling water treated at $3.0 \mathrm{~kg} / \mathrm{m}^{2}$ under OSD. The 


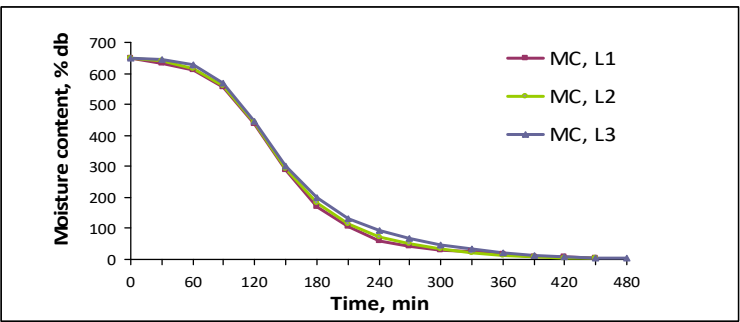

Figure 2: Changes of MC with time under GSD for CT samples.

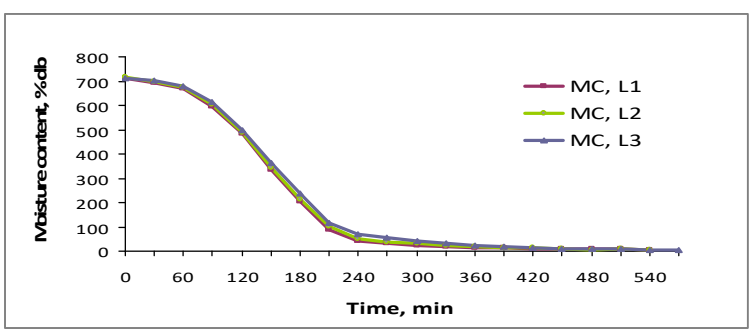

Figure 3: Changes of MC with time under GSD for BW treated samples.

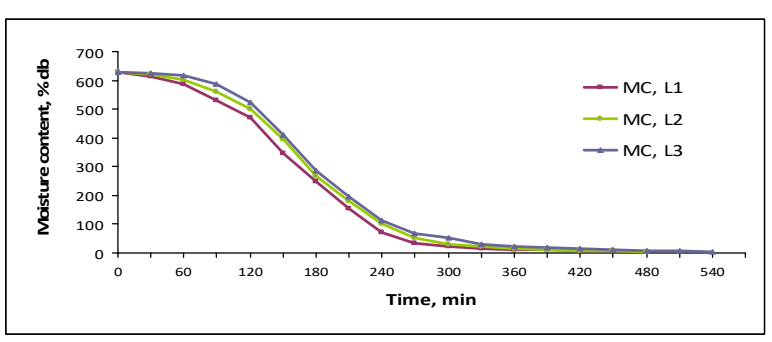

Figure 4: Changes of MC with time under GSD for UT samples.

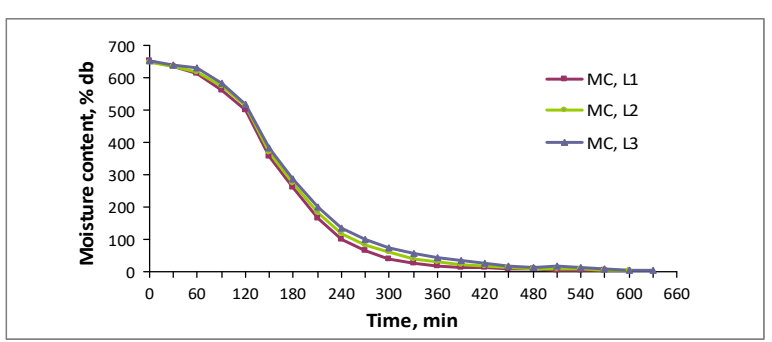

Figure 5: Changes of MC with time under OSD for CT samples.

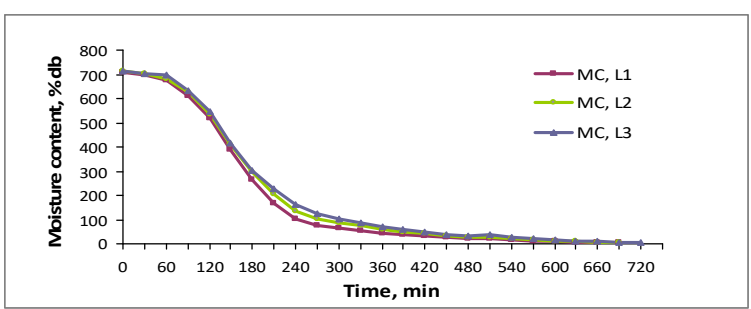

Figure 6: Changes of MC with time under OSD for BW treated samples.

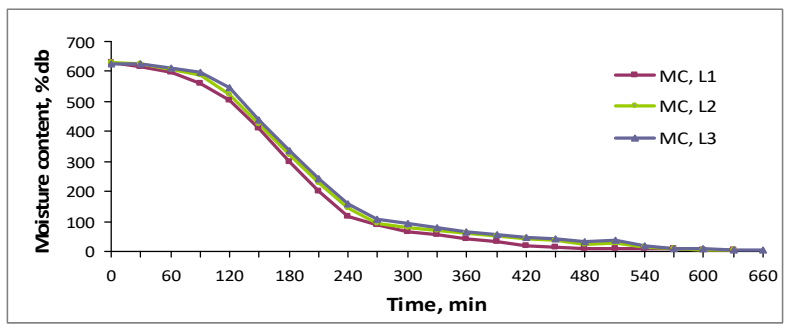

Figure 7: Changes of MC with time under OSD for UT samples.

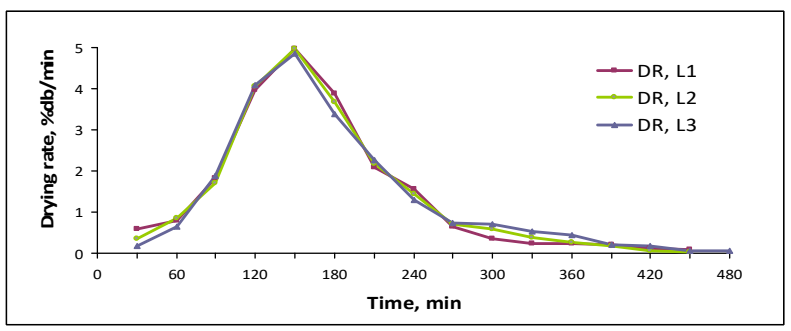

Figure 8: Variation of DR with time under GSD for CT samples.

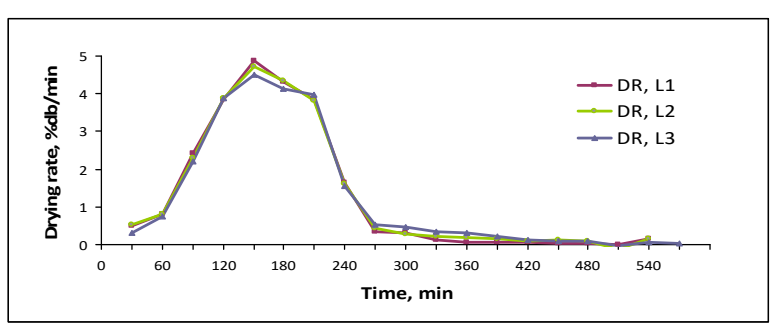

Figure 9: Variation of DR with time under GSD for BW treated samples.

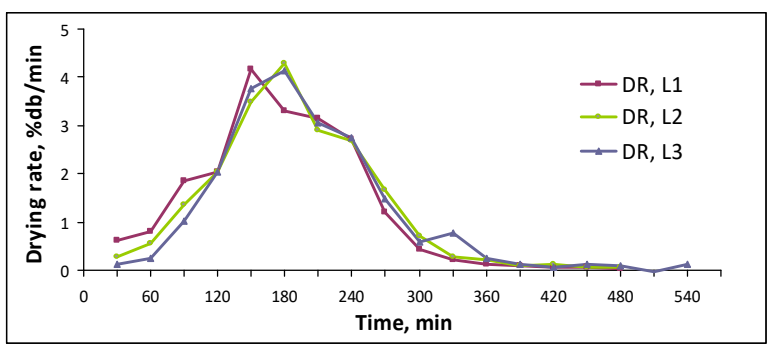

Figure 10: Variation of DR with time under GSD for UT samples.

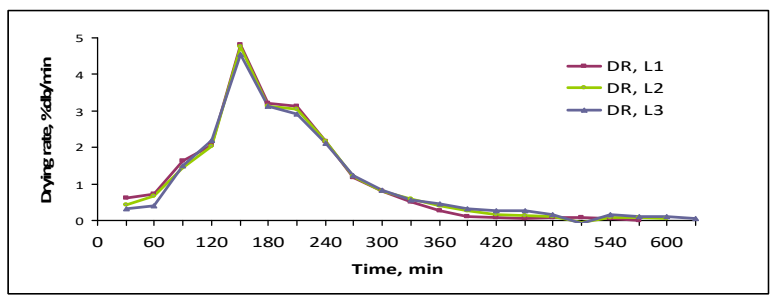

Figure 11: Variation of DR with time under OSD for CT samples. 
decreased time of drying with increasing air temperature was also observed by Sehedlou et al. (2010) and Ahmad (2013). The time of drying increased also with loading density because of the wider thickness of the drying sample. The drying time of $570 \mathrm{~min}$ at $2.0 \mathrm{~kg} / \mathrm{m}^{2}, 600 \mathrm{~min}$ at $2.5 \mathrm{~kg} / \mathrm{m}^{2}$ and $630 \mathrm{~min}$ at $3.0 \mathrm{~kg} / \mathrm{m}^{2}$ were observed under OSD for the samples treated with chemical.

Comparing the curves among Figure 2, 3 and 4, it was observed that samples treated with chemical took smallest drying time of $450 \mathrm{~min}$ at $2.5 \mathrm{~kg} / \mathrm{m}^{2}$ under SGD, UT samples took $480 \mathrm{~min}$ at $2.5 \mathrm{~kg} / \mathrm{m}^{2}$ and blanched samples took $540 \mathrm{~min}$ at loading density of $2.5 \mathrm{~kg} / \mathrm{m}^{2}$. Smallest drying time for chemically treated samples under SGD was observed because of faster removal of MC due to facilitation of opening of pore structure which resulted into more absorption of heat and rapid mass transfer. Same trend was observed earlier in green bean by Rosello et al. (1997). The decreased MC was attributed to increased evaporation of water both on the surface and inside structure of coriander due to increasing temperatures by solar heating. As per normal expectation, rapid drying took place at higher temperatures inside the SGD.

\section{Drying Rate (DR)}

The DR curves for the convective drying process of coriander leaves are shown in Figure 8 to 13, and the results of overall DR are presented in Table 2. The DR curves show the accelerated DR during initial phase of drying upto 150 minute. The faster heat and mass transfer operation at the beginning causes the accelerated DR due to internal heat generation (Lyons et al., 1972). As expected, the rapid DR was observed at high temperatures inside SGD (Figure 8 to 10) as compared to OSD (Figure 11 to 13). DR was quite low for first hour due to low temperature in the morning. As the temperature inside the drying chamber goes on increasing and when it reaches at its peak temperature, the values of drying rate were observed to be maximum. Maximum part of drying occurred between $120 \mathrm{~min}$ to $300 \mathrm{~min}$ and during this period, the drying chamber remained at high temperature under SGD.

Table 2: Overall DR at different drying conditions.

\begin{tabular}{|c|c|c|c|c|c|c|}
\hline $\begin{array}{l}\text { Drying } \\
\text { methods }\end{array}$ & $\begin{array}{l}\text { Loading } \\
\text { density }\end{array}$ & $\begin{array}{l}\text { Treat } \\
\text { ment }\end{array}$ & $\begin{array}{l}\text { Initial } \\
\text { MC } \\
\text { (\%db) }\end{array}$ & $\begin{array}{l}\text { Final MC } \\
\text { (\%db) }\end{array}$ & $\begin{array}{l}\text { Drying time } \\
\text { (min) }\end{array}$ & $\begin{array}{l}\text { Overall DR } \\
\text { (\%db/min) }\end{array}$ \\
\hline \multirow{9}{*}{$\begin{array}{c}\text { GSD } \\
42{ }^{0} \mathrm{C} \\
(30-50 \\
\left.{ }^{0} \mathrm{C}\right)\end{array}$} & \multirow{3}{*}{$\begin{array}{l}\mathrm{LI}(2.0 \\
\left.\mathrm{kg} / \mathrm{m}^{2}\right)\end{array}$} & CT & 650.75 & 4.49 & 450 & 1.436 \\
\hline & & BW & 709.31 & 4.85 & 540 & 1.305 \\
\hline & & UT & 630.24 & 4.94 & 480 & 1.303 \\
\hline & \multirow{3}{*}{$\begin{array}{l}\mathrm{L} 2(2.5 \\
\left.\mathrm{kg} / \mathrm{m}^{2}\right)\end{array}$} & CT & 649.34 & 4.92 & 450 & 1.432 \\
\hline & & BW & 714.33 & 5.02 & 540 & 1.314 \\
\hline & & UT & 627.83 & 4.87 & 480 & 1.298 \\
\hline & \multirow{3}{*}{$\begin{array}{l}\mathrm{L} 3(3.0 \\
\left.\mathrm{kg} / \mathrm{m}^{2}\right)\end{array}$} & CT & 650.35 & 4.55 & 480 & 1.345 \\
\hline & & BW & 711.25 & 5.17 & 570 & 1.239 \\
\hline & & UT & 627.24 & 5.01 & 540 & 1.152 \\
\hline \multirow{9}{*}{$\begin{array}{c}\text { OSD } \\
29{ }^{0} \mathrm{C} \\
(22-33 \\
\left.{ }^{0} \mathrm{C}\right)\end{array}$} & \multirow{3}{*}{$\begin{array}{l}\mathrm{LI}(2.0 \\
\left.\mathrm{kg} / \mathrm{m}^{2}\right)\end{array}$} & CT & 650.75 & 4.482 & 570 & 1.134 \\
\hline & & BW & 709.31 & 4.87 & 690 & 1.021 \\
\hline & & UT & 630.24 & 4.977 & 630 & 0.992 \\
\hline & \multirow{3}{*}{$\begin{array}{l}\mathrm{L} 2(2.5 \\
\left.\mathrm{kg} / \mathrm{m}^{2}\right)\end{array}$} & CT & 649.34 & 4.087 & 600 & 1.075 \\
\hline & & BW & 714.33 & 5.013 & 690 & 1.028 \\
\hline & & UT & 627.83 & 5.137 & 630 & 0.988 \\
\hline & \multirow{3}{*}{$\begin{array}{l}\mathrm{L} 3(3.0 \\
\left.\mathrm{kg} / \mathrm{m}^{2}\right)\end{array}$} & CT & 650.35 & 4.145 & 630 & 1.026 \\
\hline & & BW & 711.25 & 4.981 & 720 & 0.981 \\
\hline & & UT & 627.24 & 5.215 & 660 & 0.942 \\
\hline
\end{tabular}

decreased to $0.077 \% \mathrm{db} / \mathrm{min}$ finally. Similar non There were some unexpected interactions due to linear trends of falling rates were also observed in experimental variations. Effect of temperature on other results for both SGD and OSD conditions. overall DR for coriander leaves was clearly more 
Table 3: Analysis of variance for selected drying conditions on overall dying rate.

\begin{tabular}{|l|l|l|l|l|l|}
\hline Source & $\boldsymbol{d} \boldsymbol{f}$ & $\boldsymbol{S S}$ & $\boldsymbol{M S}$ & $\boldsymbol{F}_{\boldsymbol{c}}$ & $\boldsymbol{F}_{\text {tab }}{ }^{*}$ \\
\hline $\begin{array}{l}\text { Drying } \\
\text { method }\end{array}$ & 1 & 0.98 & 0.98 & 30.13 & 4.75 \\
\hline $\begin{array}{l}\text { Loading } \\
\text { density }\end{array}$ & 2 & 0.83 & 0.42 & 12.74 & 3.88 \\
\hline Treatment & 2 & 0.19 & 0.09 & 2.85 & 3.88 \\
\hline Error & 12 & 0.39 & 0.03 & & \\
\hline
\end{tabular}

*at $5 \%$ level of significance

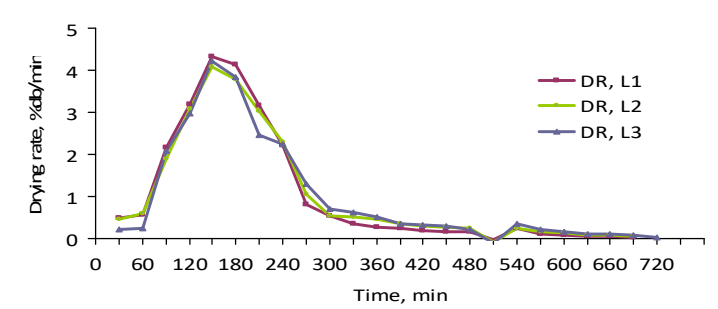

Figure 12: Variation of DR with time under OSD for BW treated samples.

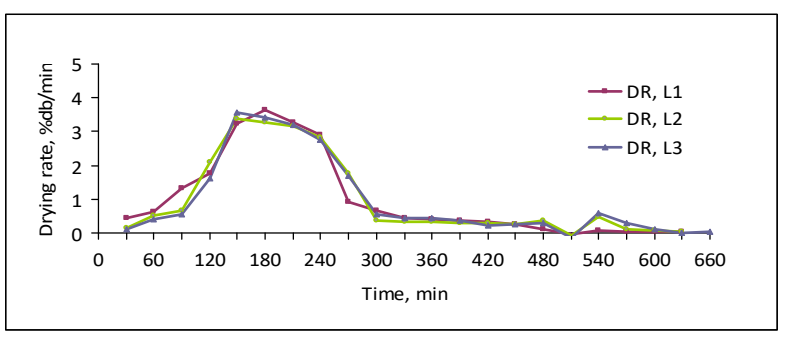

Figure 13: Variation of DR with time under OSD for UT samples.

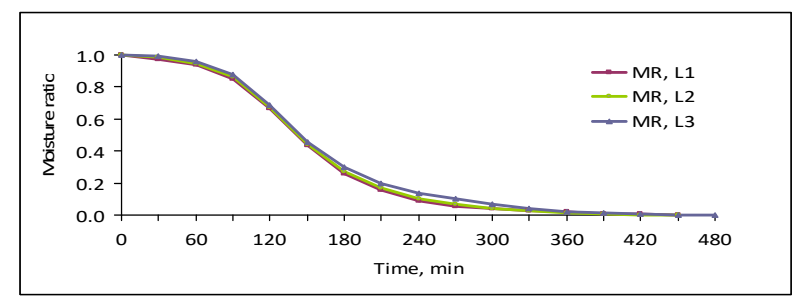

Figure 14: Variation in MR with time under GSD.

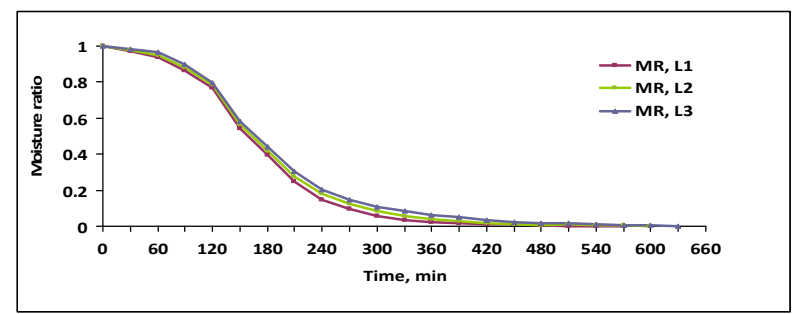

Figure 15: Variation in MR with time under OSD.

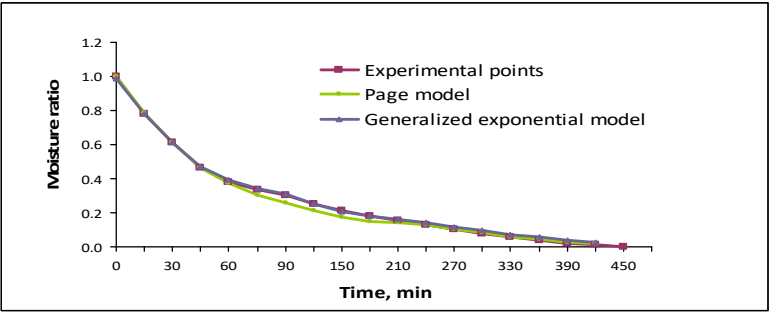

Figure 16: Performance of drying models for CT samples under SGD at $2.5 \mathrm{~kg} / \mathrm{m}^{2}$ loading density.

prominent due to increase in temperature upto 42 ${ }^{0} \mathrm{C}$ under SGD as compared to $29{ }^{\circ} \mathrm{C}$ under OSD (Table 2). Such findings are in accordance with the observations made by Kumar et al. (2011). Kumar et al. (2011) mentioned highest drying rate at $75{ }^{\circ} \mathrm{C}$ and whole drying process in falling rate period for carrot pomace. The graphs also indicate the absent of constant rate period and occurrence of drying mostly in falling rate period. Garg et al. (2014) and Akpinar et al. (2003) reported maximum drying in falling rate period for pea pods and apple slices respectively. The main reason of drying was internal mass transfer due molecular diffusion from interior region to upper surface and then evaporation from the surface (Lahsasni et al. (2004).

Overall, the DR decreased with increase in loading density and slightly low values for BW treated and UT samples than for CT (Table 2). Faster drying took place for CT samples, as compared to other treatments due to more expansion of the coriander pores treated with chemicals. Table 3 shows the analysis of variance for the selected drying conditions. Significant effect of drying methods and loading densities were observed, however, there was non significant effect of treatments $(\mathrm{P}<0.05)$.

\section{Moisture Ratio (MR)}

The variations in MR with time for experimental range of temperatures $30-50{ }^{\circ} \mathrm{C}$ under SGD and $22-33^{\circ} \mathrm{C}$ under OSD were plotted. A sample graph representing variations in MR with drying time under SGD and OSD for CT samples at three levels of loading densities are given in Figure 14 and Figure 15, respectively. The relationship shows that there was slow decrease in MR during the initial 60 minutes of drying and then rapid decrease in MR during 60 to 150 minutes of drying in all cases. However, in later stage of drying the decrease in MR was at slower rate. The curves, in general 
Table 4: Statistical results for selected drying models.

\begin{tabular}{|c|c|c|c|c|c|c|c|c|}
\hline \multirow[t]{2}{*}{$\begin{array}{l}\text { Drying } \\
\text { method }\end{array}$} & \multirow{2}{*}{$\begin{array}{l}\text { Loading } \\
\text { density }\end{array}$} & \multirow{2}{*}{$\begin{array}{l}\text { Pre } \\
\text { Treat } \\
\text { ment }\end{array}$} & \multicolumn{2}{|c|}{ Lewis Model } & \multicolumn{2}{|c|}{ Page's Model } & \multicolumn{2}{|c|}{$\begin{array}{l}\text { Generalized } \\
\text { Exponential Model }\end{array}$} \\
\hline & & & $\mathbf{R}^{2}$ & SEE & $\mathbf{R}^{2}$ & SEE & $\mathbf{R}^{2}$ & SEE \\
\hline \multirow{9}{*}{ SGD } & \multirow{3}{*}{$\begin{array}{l}\mathrm{LI} \\
\left.\mathrm{kg} / \mathrm{m}^{2}\right)\end{array}$} & CT & 0.9928 & 0.0294 & 0.9934 & 0.0291 & 0.9946 & 0.0260 \\
\hline & & BW & 0.9976 & 0.0162 & 0.9994 & 0.0085 & 0.9990 & 0.0112 \\
\hline & & UT & 0.9926 & 0.0293 & 0.9946 & 0.0258 & 0.9958 & 0.0228 \\
\hline & \multirow{3}{*}{$\begin{array}{l}\mathrm{L} 2 \\
\left.\mathrm{~kg} / \mathrm{m}^{2}\right)\end{array}$} & CT & 0.9926 & 0.0295 & 0.9948 & 0.0252 & 0.9960 & 0.0222 \\
\hline & & $\mathrm{BW}$ & 0.9825 & 0.0428 & 0.9936 & 0.0266 & 0.9910 & 0.0312 \\
\hline & & UT & 0.9928 & 0.0294 & 0.9940 & 0.0273 & 0.9956 & 0.0294 \\
\hline & \multirow{3}{*}{$\begin{array}{l}\mathrm{L} 3 \\
\left.\mathrm{~kg} / \mathrm{m}^{2}\right)\end{array}$} & $\mathrm{CT}$ & 0.9946 & 0.0254 & 0.9974 & 0.0182 & 0.9976 & 0.0176 \\
\hline & & BW & 0.9944 & 0.0252 & 0.9986 & 0.0131 & 0.9974 & 0.0176 \\
\hline & & UT & 0.9912 & 0.0317 & 0.9978 & 0.0164 & 0.9958 & 0.0228 \\
\hline \multirow{9}{*}{ OSD } & \multirow{3}{*}{$\begin{array}{l}\mathrm{LI} \\
\left.\mathrm{kg} / \mathrm{m}^{2}\right)\end{array}$} & $\mathrm{CT}$ & 0.9914 & 0.0314 & 0.9946 & 0.0256 & 0.9954 & 0.0236 \\
\hline & & $\mathrm{BW}$ & 0.9928 & 0.0287 & 0.9960 & 0.0219 & 0.9964 & 0.0209 \\
\hline & & UT & 0.9910 & 0.0322 & 0.9942 & 0.0266 & 0.9950 & 0.0245 \\
\hline & \multirow{3}{*}{$\begin{array}{l}\mathrm{L} 2 \\
\left.\mathrm{~kg} / \mathrm{m}^{2}\right)\end{array}$} & CT & 0.9916 & 0.0322 & 0.9938 & 0.0273 & 0.9948 & 0.0253 \\
\hline & & BW & 0.9936 & 0.0273 & 0.9972 & 0.0183 & 0.9964 & 0.0208 \\
\hline & & UT & 0.9932 & 0.0288 & 0.9950 & 0.0248 & 0.9958 & 0.0230 \\
\hline & \multirow{3}{*}{$\begin{array}{l}\mathrm{L} 3 \\
\left.\mathrm{~kg} / \mathrm{m}^{2}\right)\end{array}$} & CT & 0.9922 & 0.0305 & 0.9944 & 0.0266 & 0.9952 & 0.0244 \\
\hline & & BW & 0.9898 & 0.0345 & 0.9930 & 0.0291 & 0.9940 & 0.0273 \\
\hline & & UT & 0.9918 & 0.0311 & 0.9948 & 0.0253 & 0.9954 & 0.0237 \\
\hline
\end{tabular}

showed continuous decrease of MR with time. Rosell'o et al., (1997) for green bean, Gogus and Maskan (1999) for okra, and Gupta et al., (2002) for red chilli also observed the same trend. Figure 14 shows clear influence of SGD at different levels of loading densities, on the drying time for reduction of MC. MR showed that the drying of samples at $2.0 \mathrm{~kg} / \mathrm{m}^{2}$ was faster than 2.5 and 3.0 $\mathrm{kg} / \mathrm{m}^{2}$. Similar trend was observed for other temperature condition under OSD and also for BW treated and UT samples. Figure 14 and 15 shows that due to increase in temperature under SGD, there was rapid decrease in MR as compared to OSD. The time to reduce the MR was maximum at $29{ }^{\circ} \mathrm{C}$ under OSD and lowest at $42{ }^{\circ} \mathrm{C}$ under SGD. Lowest drying time to reduce the MR was reported for thin layer drying of carrot at highest temperature of $70{ }^{0} \mathrm{C}$ (Doymaz, 2004).

\section{Validity of Drying Models}

Selected models (Table 1) which describe the phenomenon of drying in falling rate period were attempted for their validity and the results are shown in Table 4. The $\mathrm{R}^{2}$ and SEE values ranged from 0.9825 to 0.9994 and 0.0085 to 0.0345 respectively, which indicates the similarity in the observed and predicted values. On the basis of $\mathrm{R}^{2}$ and SEE values, it is clear that the generalized exponential model and the Page's model was found most suited in comparison to Lewis model for experimental data. Pande et al., (2000), and Ahmed et al., (2001) reported generalized exponential model and Page's model, respectively as the best fit model for coriander leaves. Further testing of these models was made to decide the best model among all the selected models by plotting the curves of MR with drying time for observed and predicted values (Figure 16). The Page's and generalized exponential model, present over estimation in MR during the first 150 minute during drying and under estimation after 150 minute. Page's model predicted the drying behaviour very closely in later stages of drying. Generalized exponential model also predicted the drying behaviour reasonably in latter stage of drying but closeness with experimental data is more in case of Page model. Therefore, if later stage of drying is considered important than initial stage of drying then Page's model described experimental data most precisely.

\section{Conclusion}

The above study concludes that the increased drying temperature under SGD $\left(42^{\circ} \mathrm{C}\right)$ reduces the 
drying time in comparison to $\operatorname{OSD}\left(29^{\circ} \mathrm{C}\right)$, at all the selected levels of pretreatments and loading densities. Chemical treated coriander leaves at loading density of $2.5 \mathrm{~kg} / \mathrm{m}^{2}$ was found to be most suitable for drying. However, significant effect of drying method (SGD and OSD) and loading densities, and non-significant effect of treatment

\section{References}

Akonor, P. T., \& Amankwah, E. A. (2012). Thin layer drying kinetics of solar-dried Amaranthus hybridus and Xanthosoma sagittifolium leaves.

Akpinar, E. K., Bicer, Y., \& Midilli, A. D. N. A. N. (2003). Modeling and experimental study on drying of apple slices in a convective cyclone dryer. Journal of Food Process Engineering, 26(6), 515-541.

Ali, M. L., Yusof, Y. A., Chin, N. L., Ibrahim, M. N., \& Basra, S. M. A. (2014). Drying kinetics and colour analysis of moringa oleifera leaves. Agriculture and Agricultural Sciences Procedia, 2, 394-400.

Bhat, S., Kaushal, P., Kaur, M., \& Sharma, H. K. (2014). Coriander (Coriandrum Sativum L.): Processing, nutritional and functional aspects. African Journal of Plant Science 8(1), 25-33.

Bruce, D. M. (1985). Exposed-layer barley drying: three models fitted to new data up to 150 C. Journal of Agricultural Engineering Research, 32(4), 337-348.

Doymaz, I. (2004). Convective air drying characteristics of thin layer carrots. Journal of food engineering, 61(3), 359-364.

El-Sebaii, A. A., \& Shalaby, S. M. (2012). Solar drying of agricultural products: A review. Renewable and Sustainable Energy Reviews, 16(1), 37-43.

Garg, M., Sharma, S., Varmani, S. G., \& Sadhu, S. D. (2014). Drying kinetics of thin layer pea pods using tray drying. International Journal of food and nutritional Sciences, 3(3), 61.

Gogus, F., \& Maskan, M. (1999). Water adsorption and drying characteristics of okra (Hibiscus esculentus L.). Drying technology.

Hallstrom, B., Gekas, V., Sjoholm, I., \& Romulus, A.M (2006). Mass transfer in food, In: Handbook of Food Engineering, Heldman DR, Lund DB (Eds). CRC Press, Taylor and Francis Group.

Jain, R. K., Srivastav, A., \& Das, H. (2000). Dehydration characteristics of spinach in air recirculatory tray dryer. Journal of Agricultural Engineering, 37(3), 33-39.

Kaur, P., Kumar, A., Arora, S., \& Ghuman, B. S. (2006). Quality of dried coriander leaves as affected by was observed. Drying of coriander took place mostly in the falling rate period except some accelerated removal of moisture at the beginning, up to 150 minutes. Among three selected drying models, the Page's model fitted well for the data of drying experiment under the study.

pretreatments and method of drying. European Food Research and Technology 223, 189-194.

Kaya, A., Aydin, O., \& Demirta, C. (2007). Drying kinetics of red delicious apple. Biosystem Engineering, 96, 517-524.

Kumar, N., Sarkar, B. C., \& Sharma, H. K. (2011). Effect of air velocity on kinetics of thin layer carrot pomace drying. Food Science Technology International, 17, 439-447.

Lahsasni, S., Kouhila, M., Mahrouz, M., \& Jaouhari, J. T., (2004). Drying kinetics of prickly pear fruit (Opuntia ficus indica). Journal of Food Engineering, 61, 173-179.

Lyons, D. W., Hatcher, J. D., \& Suderland, J. E. (1972). Drying of a porous medium with internal heat generation. International Journal of Heat and Mass Transfer, 15, 897905.

Oliveira, S. M., Brandao, T. R. S., \& Silva, C. L. M. (2016). Influence of drying processes and pretreatments on nutritional and bioactive characteristics of dried vegetables: A review: Food Engineering Rev, 8, 134-163.

Pande, V. K., Philip, S. K., \& Sonune, A. V. (2000). Solar drying of coriander and methi leaves. Journal of Food Science and Technology, 37(6), 592-595.

Pati, G. D., Pardeshi, I. L., \& Shinde. (2015). Drying of green leafy vegetables using microwave oven dryer. Journal of Ready to Eat Food, 2(1), 18-26.

Ranganna, S. (1986). Handbook of analysis and quality control for fruits and vegetable products. Tata McGraw-Hill Publishing Ltd. New Delhi, 1112.

Rosello, C., Simal, S., Sanjuan, N., \& Mulet, A. (1997). Nonisotropic mass transfer model for green bean drying. Journal of Agriculture and Food Chemistry, 45, 337-342.

Sarimeseli, A. (2011). Microwave drying characteristics of coriander (Coriandrum sativum L.) leaves. Energy Conversion and Management, 52(2), 1449-1453.

Sehedlou, S., Ghasemzadeh, H. R., Hamdsmi, N., Talati, F., \& Moghaddm, M. (2010). Convective drying of apple: Mathematical modeling and determination of some quality parameters. International Journal of Agriculture Biology, 12,2010 
Singh, S. K., Pathak, P. K., Dwivedi, P. N., \& Sahay, C. S. (2017). Drying characteristics of berseem in a solar dryer with supplemental heating system. Range Management and Agroforestry, 38(1), 143-146.

Singh, S. K., Samsher, Singh B. R., Sengar, R. S., \& Kumar, P. (2020a). Study on biochemical properties of dehydrated coriander leaves at different drying conditions. International Journal of Chemical Studies, 8(4), 2348-2352

Singh, S. K., Samsher, Singh B. R., Sengar, R. S., \& Kumar, P. (2020b).. Sensory characteristics of dehydrated coriander leaves under greenhouse type solar dryer and its qualitative evaluation during storage. Int. J. of Current Microbiology and Applied Sciences, 9(08), 1133-1142.
Singh, S. K., Samsher, Singh, B. R. (2020c). Techno-economic viability of solar greenhouse dryer in arid and semi arid regions of India. Multilogic in Science, 10(35),1146-1150.

Singh, U., Sagar V. R., Behera, T. K., \& Kumar, S. (2006). Effect of drying conditions on the quality of dehydrated selected leafy vegetables. Journal of Food Science \& Technology, 43(6), 579-582.

Wankhade, P. K., Sapkal, R. S., \& Sapkal, V. S. (2013). Drying characteristics of okra slices on drying in hot air dryer. Procedia Engineering, 51, 371-374. 